\title{
SINTOMA E INTUIÇÃO
}

\section{ENTREVISTA COM THIERRY DE DUVE'}

\section{RESUMO}

Nesta entrevista, o crítico de arte francês Thierry de Duve discorre sobre questões presentes em seus textos, como Marcel Duchamp, sintoma e intuição, Kant (e o sensus communis), Marx, o pacto social entre o público e os artistas e a recepção retardada da obra de arte. Recorre ainda a exemplos e anedotas que vão das obras de Rivane Neuenschwander e Vermeer ao segurança do museu da Filadélfia.

PALAVRAS-CHAVE: arte moderna; artes plásticas; Marcel Duchamp;

crítica de arte.

\section{SUMMARY}

In this interview, French art critic Thierry de Duve talks over matters discussed by him in his texts, such as Marcel Duchamp, symptom and intuition, Kant (and sensus communis), Marx, the social pact between the public and the artists and the delayed reception of works of art. He also calls forth examples and anecdotes ranging from Rivane Neuenschwander and Vermeer to the security guard at the Philadelphia museum.

KEYWORDS: modern art; arts; Marcel Duchamp; art criticism.

[1] Entrevista por Afonso Luz, Thais Rivitti, Tiago Mesquita e Tina Montenegro. Edição e tradução de Tina Montenegro.
Thierry de Duve é teórico, crítico, historiador, curador e professor do Departamento de Artes Plásticas da Universidade de Lille, na França. Tem vários livros publicados sobre arte do século $\mathrm{XX}$, como Kant after Duchamp e Résonancesdureadymade. Estuda particularmente a passagem para o modernismo e tem a esse respeito uma refinada análise da obra de Marcel Duchamp e das vanguardas.

Em 2005, ministrou no Centro Universitário Maria Antônia, em São Paulo, o curso "Uma Teoria da Arte Hoje". Durante os encontros, Thierry fez análises detalhadas de obras de Duchamp, René Magrittee Marcel Broodthaers, além de uma leitura de Kant aplicada ao sistema da "arte em geral", que entrou em vigor quando o artista perdeu sua especificidade: qualquer um podia ser artista, logo qualquer coisa podia ser arte. O passo sintomático foi dado quando Alfred Stieglitz apresentou ao público uma foto da Fonte de R. Mutt, que, embora não se soubesse na época, era ninguém menos que Duchamp. 
Thierry trata dessa passagem como uma quebra de pacto social entre os artistas e o público. O gosto se espatifou em tantos gostos quanto indivíduos no Salão de Paris. Hoje, cada indivíduo deve decidir, para cada obra, se "isto é arte". O problema é que a quebra de pacto, característica das vanguardas, passou a ser considerada um valor em si, o que gerou um "academicismo das vanguardas". Thierry defende que o foco da arte seja um novo pacto, um pacto baseado em reentendimento ou reencantamento.

Paradoxalmente, para sustentar sua tese, o autor escolhe obras de artistas bastante conceituais, o que torna mais difícil a reconstituição do pacto com o "homem comum". São artistas que exploram em suas obras a linguagem e o sistema da arte. Sobre essa questão específica o texto do catálogo da exposição "Voici, 100 ans d'art contemporain" e a entrevista abaixo, concedida após a conclusão do curso em São Paulo, são bastante esclarecedores. (Tina Montenegro)

Tina - Você disse que a vanguarda se tornou uma força instituidora da tradição em certas circunstâncias da modernidade. Duchamp teria exposto como sintoma o paradoxo histórico de que toda ruptura está condenada a se tornar uma convenção.

Thierry - Não foi isso que eu disse. Por exemplo, não digo que toda ruptura está condenada a se tornar convenção. É verdade que, com o tempo, o que parecia ser uma ruptura acaba sendo totalmente aceito e, então, parecendo convenção. Não acho que foi isso que Duchamp expôs e não acho que isso explique que a vanguarda seja uma força. Ou seja, o meu problema com a sua perguntaé a formulação. Não digo que a vanguarda se tornou uma força instituidora da tradição. Digo, simplesmente, que a vanguarda é a tradição. É a continuação da tradição com meios não tradicionais.

Tina - Começamos por isso para lhe dizer que, no Brasil, as leituras de Duchamp são muito simplistas e propõem uma interpretação que vê a antiarte como vanguarda. Ironicamente, essa leitura de Duchamp cria uma tradição da vanguarda que é quase acadêmica...

Não é só no Brasil.

Tina - Hoje, isso permite enquadraras práticas artísticas em uma espécie de tradição que teria saído de Duchamp - e nós consideramos que não saiu - e propor uma abordagem fácil da história, que comporta todos os clichês sobre a morte da pintura, por exemplo. O que queremos sabervocê nos disse que não se trata de um fenômeno local - é o que acha dessa interpretação e das conseqüências sobre a recepção da arte contemporânea e sobre o pensamento e a compreensão da arte contemporânea.

A conseqüência sobre a arte contemporânea é que há um novo acade- 
micismo, como sempre houve um academicismo. Acho que a arte de grande qualidade, em todos os países e em todas as culturas, é muito rara. Talvez porque existam muitos artistas. No século XIX, todo mundo podia aprender a desenhar: desenhar se aprende, mas desenhar com genialidade não se aprende. E sempre existiu uma pirâmide com pouquíssimos grandes artistas e muitos pequenos artistas. Mas, no passado - isso é muito importante - havia uma continuidade do ofício. Ou seja, no Renascimento, um desenhista medíocre tinha o mesmo ofício que Michelangelo, quando desenhava. E, agora, não há mais meios de definir o ofício, porque, para ter ofício, é preciso ter um ofício. Mas qual é o ofício dos artistas de hoje, se é possível fazer arte com qualquer coisa? Rivane Neuenschwander tem uma peça com bolas [Globos, 2003]. Um dia, ela usa bolas, no outro dia, cola sujeiras do seu assoalho no chão [O trabalho dos dias, 1998]. Colar sujeiras do assoalho no chão, isso define o ofício de um artista? É óbvio que não. Todo mundo pode fazer isso. Logo, para julgar a qualidade do trabalho de Rivane Neuenschwander, é preciso outra coisa que não o ofício. Quando é possível fazer arte com qualquer coisa, é ao mesmo tempo tecnicamente muito fácil fazer arte, já que não é complicado aprender o gesto, e qualitativamente muito difícil. Não se sabe ainda o que vai restar da arte de hoje, é preciso esperar. Talvez muito tempo.

Tiago - Você disse que a qualidade não está na técnica. Se no sistema das belas-artes o bom trabalho de pintura é uma boa pintura, o que é um bom trabalho para Rivane Neuenschwander? No sistema da arte em geral, que qualidade das obras contemporâneas é essa?

Eu não sei.

\section{Tiago - Mas essa qualidade existe em geral.}

Sim, mas não pode ser definida. No caso de Rivane Neuenschwander, não conheço muito bem o trabalho dela. Vi duas ou três peças, mas foi o suficiente para dizer: "Existe alguma coisa aqui!". Quando vejo o Bruce Nauman, tenho outro sentimento.É completamente diferente, mas também tenho o sentimento de queé arte. Outras vezes, não sinto queé nem arte nem boa arte.

Tiago - E sobre a boa arte e a má arte? Às vezes, temos o sentimento de que algo é arte mas não é bom. Por quê?

Por quê? Eu não sei.

Thais - Mas às vezes você acha que alguma coisa é má arte?

Sim, há muitas coisas que acho ruins. É raro que eu diga que não é arte. Em geral, para mim são casos limítrofes, quando se trata de um problema de ética do artista, quando há algo antiético, não antiestético. 
Nesse momento, tenho problemas. Mas na maior parte dos casos estou disposto a aceitar que as coisas que vemos nas galerias são arte. Às vezes, fico muito entusiasmado. Às vezes, mais ou menos. Outras vezes, nem um pouco. Mas não tenho critérios. Os julgamentos sobre arte são comparativos: automaticamente, comparamos com a arte que já conhecemos e avaliamos se está no mesmo nível. Isso ficou claro quando mostrei Cabanel, Manet, Ticiano e Giorgione. Não se tem a mesma qualidade em Cabanel que em Ticiano ou Manet.

Tiago - É dificil dizer, mas você tem exemplos? Exemplos de boa arte? Eu só tenho exemplos. O que significa que não tenho definição. Não há definição.

\section{Tiago - Existe um objeto.}

Sim. Rivane Neuenschwander fez um trabalho com ovos [Mal-entendido, 2000] e um outro trabalho com baldes e água escorrendo [Chove chuva, 2002]. Usar um copo ou um baldeé arte? Em certas circunstâncias, sim. Em outras circunstâncias, não. $O$ fato de existir a "arte em geral" não suprime os diferentes meios. Ainda há a pintura, a escultura etc. Existem casos, como a arte minimalista, que estão entre os dois. Mas Gerhard Richter é pintor. De tempos em tempos, faz coisas que não são pinturas. E, de tempos em tempos, faz coisas que nos fazem questionar onde está a linha divisória. Por exemplo, quando Gerhard Richter faz janelas, temos objetos. Não é pintura. Quando faz vidros pintados por trás, temos algo que fica entre os dois. Às vezes, ele usa espelhos.É um ready-made. Mas antes de tudo Richter é um pintor. E o interessante em Richter, em [Sigmar] Polke e em outros artistas como esses é que a decisão de fazer pintura pode ser sentida na própria pintura. Portanto, enquanto o sistema das belas-artes funcionava e cada um sabia qual era o seu ofício, ficava-se dentro dos limites desse ofício. Agora, se você é estudante de arte em uma escola de arte, pode fazer o que quiser: foto, vídeo, instalação, performance.... A decisão de pintar se torna uma decisão estética em si: não vou fazer instalações, vou pintar. Então temos que comparar a qualidade dessa pintura com a instalação, a foto e as outras coisas. Antes, era preciso comparar pintura com pintura, escultura com escultura...Agora, o campo de comparação não tem limites.

Tina - Vocêfalou de sintoma e intuição, que estariam presentes na obra de arte. Por exemplo, Duchamp seria, ao mesmo tempo, sintoma e intuição do que chamamos hoje de crise da instituição tradicional da arte. Nesse sentido, a obra de arte seria, a mesmo tempo, sintoma de uma situação histórica e intuição de uma teoria da arte que está se formando e que está contida na obra. Isso nos remete a uma confusão que percebe- 
mos no debate sobre arte, entre as determinações históricas e as determinações conceituais. Você parece dizer que isso é inevitável, na medida em que uma obra de arte é produzida em um dado momento, sob certas circunstâncias, e que ela será novamente vista em um outro momento e sob outras circunstâncias históricas e culturais. Gostaríamos de saber se a recepção de uma obra de arte é sempre feita em dois tempos, se ela sempre tem um efeito retardado, e como funcionam os elementos histórico (sintoma) e conceitual (intuição) na obra de arte.

Bela pergunta, mas difícil.Sobreos efeitos retardados, penso queé sempre retardado, mesmo para o artista. Não são apenas duas vezes, podem ser três, quatro ou vinte vezes. Por que podemos representar Shakespeare ainda hoje? Porque existem efeitos retardados de Shakespeare que só vemos hoje. Porque nele ecoa a situação política atual, por exemplo, e porque encontramos atualidade nos personagens de Lady Macbeth ou Hamlet e, então, tiramos algo de novo de Shakespeare.É assim para tudo: quanto mais rica é uma obra, mais longa será sua vida.

\section{Tina - E com o tempo entendemos melhor a obra?}

Não necessariamente. O que quer dizer melhor? Eu tenho um critério de fecundidade, mais do que de verdade. Tomem o exemplo de Duchamp. No início, quando eu estudava Duchamp, também pensei que podia extrair dele uma teoria da arte. Uma teoria da arte no sentido mais tradicional do termo, ou seja, as condições necessárias e suficientes para que uma coisa seja arte. Essa foi a questão que me coloquei há vinte anos. Em um primeiro momento - eu ainda faço isso e não estou sozinho, pois muitos críticos praticam esse método auto-referencial - , fui buscar na obra. E descobri na obra de Duchamp que ela fala de suas próprias condições de existência:é preciso um objeto, um autor, um público e uma instituição. Naquele momento, eu achava que tinha uma teoria com as quatro condições. Admitamos que essa teoria vale alguma coisa.Agora, vejamos a recepção histórica de Duchamp. $O$ ready-made foi inventado em 1917, ou 1913 se considerarmos a roda de bicicleta. A primeira recepção foi dos surrealistas. Breton disse que o ready-made é a soberania da escolha do artista. $\mathrm{O}$ artista é como o rei Midas: tudo o que toca vira ouro. Tudo o que Duchamp toca vira arte. Logo, a personalidade do artista, o autor, minha segunda condição, é posta em prática. Se avançarmos um pouco no tempo, chegaremos à geração dos artistas pop, que deram ênfase ao objeto. Tomemos Arman e sua noção de acumulação, que é uma espécie de interpretação muito restritiva de Duchamp: vamos colocar os ready-made uns sobre os outros para fazer arte.É menos inteligente que Duchamp, que dizia: um ready-made de tempos em tempos, mas não dez por dia. Com Arman, são dez por dia. Talvez a Brillo box (1964) de Warhol, a pop arte, seja uma interpretação - estou simplificando - que enfatiza o 
objeto. Um pouquinho mais tarde os artistas conceituais, [Joseph] Kosuth e os outros, e também Hans Haacke e Daniel Buren de certa maneira, deram ênfase à instituição. É o caso de artistas que vão de Hans Haacke, de quem eu gosto - não sempre, mas às vezes - até Andrea Fraser, de quem não gosto, mas por razões éticas, porque não gosto de ser um espectador de museu manipulado pelo artista. Então, vimos o autor, o objeto, a instituição e falta ainda dar ênfase ao espectador. Duchamp disse: os observadores fazem os quadros. E eu ainda espero - ainda não vi - uma espécie de quarta recepção dele que dê ênfase à responsabilidade do espectador. Talvez isso esteja emergindo agora em algumas correntes da arte contemporânea. É claro que vi isso em Duchamp, mas outros teóricos poderão ver outra coisa daqui a vinte anos; e outros artistas reagirão a outra coisa. Isso se Duchamp continuar a ter a influência que tem hoje. Talvez não tenha mais.

Sintoma e intuição é o título que quero dar ao meu segundo livro. Meu projeto é fazer quatro volumes. O primeiro conterá praticamente tudo o que expus aqui em São Paulo, embora outro dia tenha decidido, aqui mesmo, que a parte sobre a arte minimalista, sobre [Clement] Greenberg e [Michael] Fried, ficará em Sintoma e intuição. Porque... o queé um sintoma? Quero tirar as conotações negativas da palavra. Um sintoma é quando o médico diz: "Você tem os sintomas da gripe". Ou o psicanalista diz: "Vocêé neurótico, esses são os seus sintomas". Um sintoma é um sinal.É preciso saber lê-lo.É um indício. E uma intuição é a mesma coisa, mas do lado do criador do sintoma.Acho, por exemplo, que Fried teve uma intuição formidável para compreender a arte dos dois últimos séculos quando inventou a oposição entre teatralidade e absorção. E então isso se torna uma maneira de decodificar os sinais através da história. Acho que Don[ald] Judd teve uma intuição, mas que ao mesmo tempo é um sintoma, quando inventou a expressão objeto específico. A intuição e o sintoma são a mesma coisa. Acho que Don Judd quer se defender de Duchamp. Contra o vale-tudo. "Não, não vale tudo. Os meus objetos não são objetos ordinários, são objetos específicos." Um outro sintoma-intuição: Daniel Buren. Ele usa tecido ready-made, fabricado industrialmente, e quando pinta — não sobre papel, mas sobre tela -, pinta duas listras brancas exteriores. É para dizer: isso não é ready-made, é pintura.Acho queéuma interpretação ingênua da pintura. É uma espécie de intuição, mas não uma boa intuição. Talvez mais um sintoma. E seria sintoma de quê? É o sintoma do fato de que, nos anos 1960, havia um problema com a arte em geral. Na França, o grupo Supports/Surfaces reivindicou especificidade. Escreveram muitos textos teóricos. Tinham uma revista que se chamava Peinture, Cahiers Théoriques, na qual as palavras especificidade eautonomia da pintura, contra a arte em geral, voltaram com muita força. Duchamp é rejeitado por esse grupo por representar, segundo eles, uma espécie de prática mecânica. 
Bom, tudo isso está embrulhado no vocabulário marxista da década de 1960. Mas isso é o que chamo de sintoma e intuição. Muitas vezes são a mesma coisa, mas alguns são mais ricos do que outros. Isso não é a mesma coisa que o julgamento. Por exemplo, acho que Michael Fried, em Art and objecthood, foi muito clarividente sobre a teatralidade da arte minimalista, porém ele rejeita a arte minimalista por causa disso. Eu, não. Então, o julgamento não é necessariamente a mesma coisa que a interpretação. E o sintoma deve ser interpretado.

Tiago - Você fala de uma crise da arte em geral. Eu não entendo qual é a questão da crise.

A questão é que o novo sistema, arte em geral, enfim chegou. A mensagem foi colocada no correio em 1917 e em 1960 aconteceu algo. Alguma coisa mudou os conceitos da arte. Existem os que abraçam com entusiasmo a nova situação - os artistas pop estão aí - e os que se defendem contra isso. A questão da especificidade dos meios é crucial. Ela ainda é crucial para alguém como Rosalind Krauss, que recentemente escreveu sobre[James] Coleman, Broodthaers e por aívai. Ela se pergunta se um artista pode inventar um novo meio. É definitivamente uma forma de lutar contra o vale-tudo.

Tiago - Então eu não entendo o caso de Jasper Johns, porque é antes da arte pop. É muito diferente de Arman, por exemplo. Não entendo qual é o lugardele.

Isso me leva a uma pequena idéia que pode ser útil para vocês. A idéia é que as obras de vanguarda usam uma estratégia de vacina: eu inoculo a doença para que vocês reajam contra ela e desenvolvam anticorpos. É toda a história da vanguarda.Jasper Johns é um caso particular.Aquestão é, de novo, para os minimalistas dez anos depois, a fronteira entre a pintura e o objeto. O que é uma bandeira? É um objeto. Quando se trata de uma bandeira pintada cujos limites são os da tela, temos, ao mesmo tempo, a representação de uma bandeira, uma bandeira e um objeto. Mas, se eu pintasse uma bandeira tremulando ao vento, seria a representação de uma bandeira. Um alvo é um alvo, logo é um objeto, mas é pintado. Jasper Johns é sem dúvida um pintor, portanto uma pincelada de Jasper Johns é uma maneira de dizer que aquilo não é um alvo, é uma pintura. Mas a imagem diz que é uma pintura que corre o risco de ser tomada por objeto. Então, se objecthood é a doença, à la Michael Fried, Jasper Johns se inoculou um pouco da doença para reagir. Vou dar outro exemplo, do século XIX: o modernismo, queé muito importante e muito fácil de entender, é uma reação contra a ameaça da época. A arte está ameaçada a partir do momento em que qualquer coisa pode ser arte e qualquer um pode ser artista. Quais são as grandes ameaças no século XIX? Na minha conferência, falei da multidão 
nos salões de pintura, o que significa que o gosto se torna o gosto de qualquer um. Por mais que sejamos totalmente democratas e politicamente progressistas, é evidente que o gosto dos operários e dos camponeses é menos educado que o gosto dos burgueses e aristocratas. Assim, há uma queda do gosto. Era uma ameaça. Podemos abordar a mesma questão pela técnica: a invenção da fotografia é uma ameaça para os pintores. O que é a invenção da fotografia? Clique! É uma pintura ready-made. Como reagir à ameaça da fotografia? Há três maneiras de reagir. A primeira é dizer: "Vou me tornar fotógrafo". Daguerre era pintor. Abandonou a pintura, fez fotografia e se tornou um fotógrafo muito bom. "Perdi, mas ganhei em outro meio." Segunda possibilidade: vou competir com a fotografia. A fotografia é muito realista. Vou me tornar muito realista. E essa estratégia vale tanto para pintores muito acadêmicos como [William-Adolphe] Bouguereau, cujo efeito de pele humana é fenomenal, ou para [Gustave] Courbet, cujo resultado não é realista no sentido naturalista, mas disse: "Agora, o âmbito da pintura é o âmbito do visível. Não se pode pintar um anjo, porque um anjo não é visível". Não é a mesma solução que Bouguereau adota, mas é a solução de vanguarda: ele incorpora a sensibilidade da fotografia. Outro exemplo: Monet. Cézanne dizia: Monet nada mais é do que um olho, e que olho! Isso quer dizer, por metáfora, que Monet, seu corpo, sua mão, seu olho são uma máquina fotográfica e a tela é a superfície fotossensível. Então, para ele, pintar vira registrar a luz. Ele compete com a fotografia, porque a fotografia é instantânea e Monet fica lá, diante da catedral de Rouen, querendo captar a luz do meio-dia. Isso é interessante porque quando [Andy] Warhol diz: "Eu quero ser uma máquina”, está falando de Monet. E Cézanne disse - não me lembro exatamente - que o pintor nada mais é do que uma máquina fotográfica cujos filmes são revelados por banhos de sabedoria. Ele usou a metáfora da fotografia para falar dele mesmo. É o que eu queria dizer sobre a vacina. [Jean Auguste Dominique] Ingres já dizia: "A fotografia é muito bonita, mas não é bom dizer isso...". Os pintores se sentiram sem trabalho porque uma máquina podia fazer o trabalho deles. É exatamente como acontece agora com os computadores. Antes, era preciso um linotipista para fazer um livro. Hoje, envio o arquivo eletrônico ao editor. Não há mais linotipistas, e há pessoas que são substituídas por máquinas todos os dias. É o problema da economia moderna, evidentemente, é é mesma coisa com a arte.

Afonso - Você disse que o surgimento das técnicas de reprodução mecânicas da imagem, como a fotografia, gerou uma revolução, no sentido em que a atividade artística se considerou cada vez mais mecânica. Essa dinâmica teria cumulado nas pinturas de Andy Warhol, o momento extremo desse "desejo do artista de virar uma máquina de pintar". Você 
pode nos explicar a sua reflexão e também como vê isso em um novo momento histórico de revolução tecnológica, no qual aumentamos ainda mais nossa capacidade e nosso desejo de manipulação da natureza e da vida?

Não sei. Não tenho resposta à sua pergunta. Acho apenas que isso que disse sobre a estratégia da vacina ainda é válido. E que, por exemplo, diante das novas tecnologias, há artistas que se precipitam e se tornam especialistas da máquina: sabem manipular muito bem a imagem virtual, mas são escravos da máquina. Há outros que usam a velha estratégia de Warhol e Cézanne: eu me torno a máquina. Essa história é muito complicada. Marshall McLuhan dizia que o conteúdo de uma arte é outra arte. O conteúdo do cinema, no início, era o teatro. O conteúdo de um novo meio é o antigo meio. Acredito que poderíamos encontrar exemplos de peças de teatro que integram a sensibilidade do cinema. O artista faz o caminho inverso da tecnologia. Vejam a invenção do automóvel: os primeiros modelos de automóveis tinham a forma de uma carruagem, mas sem os cavalos. O progresso do design do automóvel era se desfazer do antigo modelo. $\mathrm{Na}$ arte, muitas vezes, mas não sempre, é o contrário. Acho que aprendemos mais sobre o trauma da fotografia, sobre o choque que a invenção da fotografia foi no século XIX, vendo os pintores do século XIX do que vendo os fotógrafos. Falei de Monet há cinco minutos, mas poderia ter falado de Manet:é como se fosse uma fotografia tirada com flash.AOlympiaéum instantâneo. Aliás, na Olympia, há um gato na ponta da cama. Ele está eriçado. E o corpo da Olympia é achatado, se olharmos a pintura e a compararmos com Ticiano, que tem toda aquela carne. A crítica da época disse:é uma mulher de borracha,é papelão, são imagens achatadas... Mas a sensibilidade fotográfica é o flash, e o flash achata. Então, aprendemos mais sobre a fotografia vendo Manet, Monet e os impressionistas, ou Seurat, do que vendo fotos. Os grandes fotógrafos do século XIX são fotógrafos que não querem ser artistas. Os que querem ser artistas querem imitar a pintura. É o movimento pictorialista na fotografia. [Léonard] Misonne, [Robert] Demachy e gente assim faz fotos imitando a pintura e está dez anos atrás dos impressionistas. Os impressionistas são mais modernos do que os fotógrafos que imitam os impressionistas.

Tina - Vocêfalou de um pacto, que não se sabe mais quem é o público e quem são os artistas. Como está o pacto hoje? Ele se recompôs?

Thais - Eu tenho a impressão de que isso tem a ver com ofato de que, na arte contemporânea, há poucos espectadores. Não sei se você concorda. Sim e não. Às vezes, sou muito pessimista; outras vezes, muito otimista. Sou pessimista quando a arte requer do espectador um ato $a$ priori, um pacto anterior. Ou seja, quando tenho o sentimento de que o 
artista me pede que saiba queé arte antes de entrar na galeria. Quando se trata de códigos. Por exemplo, de vinte anos para cá existe muita arte que faz citação. É uma arte que extrai o seu estatuto das pessoas importantes que cita. Não é muito interessante.

Thais - Não sei se entendo corretamente o que você disse, mas, de uma certa maneira, na obra de Duchamp o espectador deve saber algo sobre arte contemporânea para compreender um ready-made.

Talvez sim e talvez não. É claro que conhecer a história da arte ajuda. Mas o que você quer dizer com "compreender a arte contemporânea"? Saber? Ter tido experiência pessoal? Sim. Deixe-me contar dois sintomas. São os sintomas que às vezes me fazem ficar muito otimista. É verdade que o mundo da arte de hoje tem tendência a se fechar. $\mathrm{O}$ mundo da arte não é todo mundo, são as pessoas que vão às galerias. Entretanto, de tempos em tempos, a gente se diz: não é verdade, quando vamos à Bienal de Veneza ou São Paulo, ou à Documenta, vemos pessoas. Vejo que essas pessoas nunca vão a uma galeria, mas vão à Documenta e parecem interessadas. Isso me enche de alegria, porque penso: então isso quer dizer que a arte contemporânea fala a essas pessoas. Mas existe um outro sintoma, muito raro. Foi umas das experiências mais emocionantes da minha vida. Há vinte anos, quando eu dava aulas no Canadá, fui com os estudantes até a Filadélfia para ver as obras de Duchamp. Tive então a ocasião de explicar o Grande vidro diante do Grande vidro. O segurança da sala escutou, escutou, escutou e depois veio me procurar e disse: "Eu vou lhe dar a minha interpretação". Esse cara tinha uma sensibilidade incrível para a arte. Depois, fomos à sala dos Brancusi e ele entendia tudo. Por sensibilidade, não por conhecimento. Eu disse: "Fantástico! Você fala melhor de arte do que eu! Está aqui há muito tempo?”. E agora vem a melhor parte da história: ele estava lá fazia três meses! Era caminhoneiro e por causa de um problema nas costas não podia mais dirigir caminhão. Procurou um outro trabalho e encontrou aquele, como segurança do museu. Era uma prova para mim de que, de tempos em tempos, você acha pessoas que de certa maneira são artistas: um artista que não sabe queé artista. Ele não precisa saber no sentido de ter estudado história da arte nos livros de história da arte ou na universidade. Porém isso é evidentemente raro, muito raro. Quando tenho dúvidas sobre o sensus communis, volto sempre àquele homem da Filadélfia. Para mim eleé a prova de que o sensus communis existe.

Tiago - Gostaria de entender melhor como vai o pacto social nos dias dehoje.

A maior parte do tempo, ele está mais ou menos reconstituído. Isso significa que o entusiasmo que às vezes sinto quando vejo a multidão 
na Bienal de Veneza não é um entusiasmo extraordinário. Porque acho que as pessoas, essas que vão à Bienal, são suficientemente bem informadas para saber que podemos aceitar coisas muito estranhas. Elas prestam atenção, mas não são necessariamente sensíveis por isso. E elas são enganadas por uma arte que costuma ser muito ruim. O que me interessa são as rupturas de pacto. E eu teorizo, já que o meu trabalho é fazer teorias, a partir da posição do adversário, ou seja, a partir da posição do homem comum, que rejeita Duchamp, ou a arte de hoje, ou Carl André. Por exemplo, fiz uma exposição em Bruxelas que se chamou Voici e tinha tudo a ver com a idéia de reconstituir o pacto de outra maneira.

Tiago - Há pactos que vêm depois do pacto anterior. Essa tentativa de novo pacto é uma reivindicação de universalidade?

Thais - Para voltar a Kant.

Vou falar tomando o exemplo de Voici. Na entrada da exposição, a primeira sala, fica claro que fiz um esforço: misturei coisas para que as pessoas que estivessem prontas para aceitar que Rodin é um artista fossem obrigadas a olhar para Kiki Smith. Pessoas que aceitam uma visão humanista do homem gostam da bela escultura estilizada com uma mão no coração, que desejava as boas-vindas aos espectadores. Mas tinha também uma obra de [Bernd] Lohaus, que eram simplesmente pedaços de madeira no chão. Vocês não conhecem esse artista, é muito bom escultor. Era muito mais difícil para o homem comum assinar o pacto com Lohaus do que assinar o pacto com a escultura estilizada. Um homem me escreveu uma carta, furioso: "Fui à exposição com a minha mulher e, antes de pagar as entradas, eu vi isso. [Lohaus] Pagar cinco dólares por isso?! Nunca!". Para mim, ele é o herói da exposição, porque isso mostra que às vezes o pacto ainda é problemático e que esse cara levou a arte contemporânea mais a sério do que aqueles que estão prontos a aceitar qualquer coisa e não prestam atenção. Logo, não consegui reconstituir o pacto com esse homem, mas fiz um esforço, porque respondi. Escrevi e coloquei dois ingressos gratuitos no envelope. Disse-lhe: "Se você quiser, não olhe para aquilo. Você verá. Há um belo Matisse e um Picasso. Talvez isso lhe ajude". Não sei se o homem voltou, mas essa é a minha idéia de pacto e de reconstituir o pacto.

Tina - Vocêfalou de novo do pacto. Você fala muito de direito. História da arte como jurisprudência. Vanguarda como uma espécie de mudança de jurisprudência. Vocêfala também de pacto rompido e indefinição das partes. Quero saber qual é o lugar do direito no seu pensamento.

O lugar do direito? Como o julgamento estético é um julgamento, podemos fazer a analogia com um juiz que julga um assassino. Mas a minha idéia de jurisprudência é muito fácil. É que a história da arte é escrita duas vezes. Ela é escrita uma vez nas obras e uma vez no discurso 
sobre as obras. As obras são conservadas no museu. Quando o meu carro tem 200 mil quilômetros, eu o jogo fora, não vou conservá-lo. Também não conservamos todas as obras de arte. Muitas são destruídas. Bombardeios, guerras ou simplesmente o uso. Mas o ofício de historiador da arte e o ofício de curador de museu são mesmo engraçados. Há pessoas que passam o tempo restaurando coisas muito frágeis, sobretudo obras de arte contemporânea feitas com materiais perecíveis. Por trás de cada decisão de conservar uma obra, existe um julgamento e esse julgamento diz:vale a pena conservar isso. A jurisprudência é isso. Quando Vermeer pintou seus quadros, ele os mostrou. Vale a pena ser mostrado. Depois, alguém compra um Vermeer e seu filho ou filha diz, cinqüenta ou vinte anos depois: "Isso vale a pena ser conservado. Fico com ele, não vou jogar fora. Há quadros do meu avô que estavam no sótão e que jogamos fora. Mas nós mantivemos os Vermeer". Vermeer é um caso particular, porque foi esquecido durante dois ou três séculos, porém não totalmente, porque se assim fosse teríamos jogado fora seus quadros. Em um determinado momento no século XIX, ele se torna um grande pintor.A jurisprudência é isso. Há um primeiro julgamento, depois um segundo, depois um terceiro, um quarto, um quinto e não pára, não há julgamento final.

\section{Tiago - A jurisprudência é aceita por meio de uma discussão? É um consenso?}

Sim, mas nunca é de uma vez por todas. Há uma antiga tendência na história da arte que é revisionista. Há revisões, às vezes revisões perigosas. Quando o Museu d'Orsay em Paris abriu, por exemplo. Ali era uma estação de trem e decidiram fazer um museu do século XIX. De repente, todas aquelas pinturas e esculturas acadêmicas que não víamos porque tinham desaparecido iam poder ser revistas. Havia o Louvre, havia um museu de arte moderna, havia o Jeu de Paume, onde estavam os impressionistas, mas os artistas acadêmicos não eram vistos. Por isso, fiquei muito contente que pudessem enfim ser vistos. Poderíamos ver Cabanel e Manet, ver a diferença e entender por que Manet é melhor. Mas a idéia por trás da criação do Museu d'Orsay era muito mais ambígua do que isso. E existe o perigo de que a história da arte revisionista diga: "Não, não. Cabanel e [Thomas] Couture são artistas muito importantes. Talvez melhores do que o Manet". Quem sabe como será o gosto em quinhentos anos? Ou em vinte anos?

\section{Tiago - Mas o debate fica mais importante.}

Só que não há debate. Vou citar um exemplo que me deixou tão furioso que mandei um artigo para o Libération. Era uma exposição no Museu d'Orsay, chamada Manet-Velázquez. Não havia somente Manet e Velázquez, mas também [Jusepe de] Ribera, [Francisco de]Zurbarán e 
outros pintores espanhóis da época. Fiquei muito contente de ir, porque vemos essas comparações de quadros nos livros de história da arte, então que prazer poder vê-las ao vivo! Fiquei furioso, porque a confrontação entre dois quadros foi sistematicamente evitada. A gente entrava na primeira sala e encontrava Velázquez, Velázquez, Velázquez. O filósofo de Velázquez [Menipo]. E o filósofo de Manet? Onde estava ? Não estava lá. Então, me virei e vi o soldado morto, que era atribuído a Velázquez no tempo de Manete nãoé mais, vem da coleção Portalis, de Paris. Olhei: onde está o Toureiro morto, de Manet? Não estava lá. Me perguntei: que tipo de exposição é esta? Em outra parede, o São Francisco em meditação, de Zurbarán, ajoelhado com um crânio. Bela pintura! Onde está oMonge ajoelhado, de Manet? Então, dei a volta na parede e ele estava lá. Exatamente atrás. Não era possível vê-los juntos. Fiquei furioso. Escrevi o artigo e falei com o diretor do museu depois. O que eu penso - não tenho provas - é que eles tiveram medo. Os conservadores tiveram medo. Como vocês vêem, não sou conservador. Eu o sou apenas na medida em que quero preservar as obras-primas do passado e não deixar que sejam destruídas. Mas o ponto de vista conservador numa exposição dessas é dizer: Manet e Velázquez são grandes pintores que dialogam através da história.Éum blablablá humanista. Ao entrar, o espectador deve saber que Manet e Velázquez são grandes pintores. Mas eu digo que não. Se tivessem colocado o Monge ajoelhado ao lado do Zurbarán, teríamos visto como o Monge ajoelhado é mal pintado.É horrível, duro, bruto, ao lado do Zurbarán. Isso teria dado ao espectador de hoje a possibilidade de ter um pouquinho da experiência estética que os espectadores do tempo de Manet tiveram, quando Manet era tão novo que o veredicto do júri foi: "Isto não é um quadro". Vocês entendem? A mesma coisa vale para todos os outros: Mayas no balcão, de Goya, e O balcão, de Manet... Havia todas as comparações, porque todos os quadros estavam lá. Mas o Toureiro morto estava quatro salas adiante. Eu sonho em fazer uma exposição onde, pelo menos uma vez, possamos colocá-los juntos. Então saberemos o que é julgamento estético em toda a sua brutalidade.

Afonso - A produção de arte no Brasil provém de uma situação cultural e social muito diferente da européia e da norte-americana. Ela se diferenciou, por exemplo, por intermédio de um Hélio Oiticica, gerando contramodelos para a experiência estética ocidental. Você acompanha essa produção? Ou essa diferença seria apenas uma questão de rótulo multiculturalista para o consumo do mercado internacional de feiras e exposições?

A resposta à última pergunta é não, não é de forma alguma só isso. Ao contrário. No entanto, o que me choca na sua pergunta é que não tenho nem um pouco a mesma impressão que você. Tenho a forte impressão 
de que a Europa é aqui. Tenho sobretudo a impressão de que a América Latina é o reservatório cultural da Europa do futuro. A Europa está em decadência, mas vocês ainda têm o futuro econômico e portanto o futuro cultural, e é importante que conservem essa herança européia. Eu sou muito europeu, mas sempre sou mais europeu quando estou fora da Europa do que quando estou na Europa. Todos os movimentos, concretismo, neoconcretismo e outros, saem da arte européia. Hélio Oiticica tem uma formação rigorosamente formal. Evidentemente, há um contexto, acho que as arquiteturas frágeis de Oiticica, os parangolés etc. nasceram da cultura do samba e da favela. Estou dizendo clichês. Desculpem-me, não sou brasileiro, portanto não conheço bem. É evidente que a cultura popular é uma fonte, é assim que todas as culturas se renovam: sempre bebendo na fonte da cultura popular. Contudo há uma herança européia extremamente forte na arte brasileira.

Afonso - Em uma série de artigos publicados na revista October, você fez uma análise de quatro artistas fundamentais, que delimitam os horizontes da produção contemporânea: Joseph Beuys, Warhol, Yves Kleine Duchamp. Você acha que eles ainda são referência para a esfera de valores da produção de arte? Que artistas surgem atualmente com a força de instaurar questões atuais e propor valores para a arte?

Não estou propondo valores para a arte. A palavra valoré problemática para mim.

\section{Afonso-A pergunta é: o que é a arte?}

Não é possível responder o que é a arte, mas eu talvez possa tentar responder esclarecendo alguns de meus conceitos. Por exemplo, eu distingo o conceito de valor e o de qualidade. Acho que o conceito de qualidade é estético e é medido pela força do meu sentimento. Não há outro meio. É sempre uma coisa afetiva. A sensação também. É sensual, se quiserem. No fim, de alguma forma, é sempre da ordem do desejo. Valor é uma palavra econômica, um conceito econômico. Um dos meus livros trata unicamente disso. É que vocêcitou a October, mas em francês era um livro, Cousus de fil d'or [Amarrados com fio de ouro]. É um livro engraçado, porque foi uma encomenda. Eu tinha que escrever sobre quatro artistas. Eu me perguntei o que podia unificá-los, e foi Marx que serviu. É um livro um pouco estranho na minha produção, porque é sobre Marx, sobre os conceitos de Marx e sobre a sobreposição. Começou assim porque, naquele momento, tive uma intuição: a criatividade em Beuys era a mesma coisa que a força de trabalho em Marx; e então comecei a ler Marx seriamente. Tinha lido um pouco quando era estudante, como todo mundo, mas nunca seriamente. Devorei todo o primeiro volume do Capital, mais os escritos de juven- 
tude. Enfim, uma série de coisas que li muito, muito rápido, em um mês. Devez em quando fazia anotações. De repente, tudo se encaixou. Acho que existe de fato - é uma das características da modernidade - uma espécie de superposição do campo conceitual da economia,em termos de valor, de força de trabalho, alienação, todos esses conceitos, e o campo da estética. Evidentemente, esse livro é uma tentativa de desconstruir, mostrar que essa superposição é um fenômeno histórico contingente, e não um fenômeno fundamental da natureza. $O$ século $\mathrm{XX}$ pensou a arte dentro de um paradigma econômico, da mesma maneira que, nos tempos antigos, se pensava a arte dentro de um paradigma religioso. O paradigma econômico e o político comprimiram o religioso. Quando digo econômico, quero dizer economia política no sentido de [David] Ricardo, Marx e toda a tradição. Não estou falando de quanto custa. Estou falando dos conceitos fundamentais: antes, era a religião, o culto, o valor do culto; hoje, é a política. Hoje se fala muito da estetização do mundo cotidiano. Do ponto de vista crítico adorniano, é um conceito negativo, mas é um conceito que pode abrir novos campos positivos. A noção de qualidade de vida, toda uma série de noções que vêm da ecologia - comer melhor, não comer porcaria, ter boa saúde... - uma espécie de ética à la Michel Foucault dos últimos livros, uma espécie de ética antiga ("Mens sana in corpore sano"), isso está voltando e é uma forma muito positiva de estetização da vida. Não se trata necessariamente de valor de mercado, publicidade ou decoração.

Afonso - O que você ach a dessa repolitização da produção contemporânea, que recuperou práticas situacionistas e reordenou o campo de circulação de objetos e ações contra as instituições tradicionais de valor, por meio de dinâmicas comunitárias? Refiro-me aos coletivos de artistas è̀s redes de integração digital, que fazem trocas de produtos estéticos fora do mercado, refletem sobre os fluxos migratórios, escolhem a cidade como campo de intervenção ou, como diz Rancière, lutam pela "partilha do sensivel" em um espaço e um tempo de atividades cotidianas. $\mathrm{Ou}$, ainda, que relação existe entre estética e política?

A última pergunta é tão vasta que certamente não poderei abordá-la aqui. Quanto ao resto, o que acabei de dizer sobre a estetização do cotidiano entra um pouco aí. Claro que sou favorável a todas as experimentações e a tudo que você diz sobre reencontrar a comunidade, sobre as dinâmicas comunitárias, os coletivos de artistas etc. Porém não faço disso uma ideologia, não faço uma doutrina. Tenho muita desconfiança do comunitarismo, pelas razões que expliquei no outro dia: arte negra para os negros, arte gay para os gays... Quanto aos coletivos de artistas, depende.É toda a questão da divisão do trabalho na arte.Acho que, infelizmente, um dos mitos da modernidade, justamente no lado marxista, foi acabar com a divisão do trabalho. Porque a divisão do 
trabalho, como diz Marx, é uma divisão técnica do trabalho. Quer dizer que você é encanador e eu sou padeiro. Mas também é uma divisão social do trabalho. Quer dizer que você está em cima e eu estou embaixo. $O$ mito dos coletivos é a igualdade, naturalmente. $O$ perigo dos coletivos é como um ditado que diz que um camelo é um cavalo desenhado por um comitê. Em compensação, existem artes onde a divisão do trabalho é muito forte e isso não impede que sejam artes maiores. O cinema não pode ser feito por uma só pessoa,é uma equipe. O teatro também. Você pode pintar sozinho em casa, mas não pode fazer teatro sozinho. Talvez uma performance, porém não montar uma peça de teatro. Logo, não tenho nada contra a arte coletiva, mas pintar um quadro coletivamente não costuma ter bons resultados. Melhor assim. O importante é que esse tipo de experiência sempre aconteça. A história da modernidade é cheia de reagrupamentos e cisões, o tempo todo. No entanto, é comum os reagrupamentos serem feitos em nome de uma ideologia em vez de uma prática real. Na minha opinião isso não produz muitos resultados. Quanto a Rancière, eleé interessante, mas não conhece a história da arte suficientemente bem, não presta atenção a singularidades. Ele tem amplas categorias que aplica sobre a história. É útil, sedutor, porém eu tento combinar uma visão ampla com análises específicas. Por exemplo, ontem passei duas horas analisando um único trabalho de Broodthaers.

\begin{tabular}{l}
\hline $\begin{array}{l}\text { Recebido para publicação } \\
\text { em } 8 \text { de abril de } 2007 .\end{array}$ \\
\hline NOVOS ESTUDOS \\
CEBRAP \\
78 , julho 2007 \\
pp. $211-226$ \\
\hline
\end{tabular}

